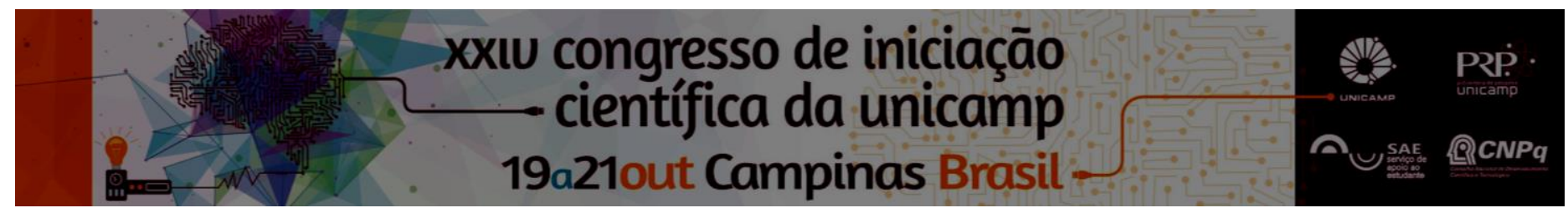

\title{
SISTEMA DE COMPOSTAGEM EM PEQUENA ESCALA
}

\section{Letícia S. Moreira*; Cláudio Gabriel S. Moura*(Bolsistas PIBIC- EM/UNICAMP); Graziela Matsunaga(Monitora);}

\author{
Aline R. Ramos (Monitora); Carmenlucia S.G. Penteado (Orientadora)
}

Faculdade de Tecnologia - FT/UNICAMP

\section{Resumo}

Este trabalho se iniciou com pesquisas sobre resíduos sólidos domiciliares e sistemas de compostagem domésticos. Foram montadas e monitoradas três diferentes comsposteiras domésticas, na Faculdade de Tecnologia da UINICAMP em Limeira-SP, observando as características e resultado final de cada uma delas. Foram elaboradas apresentações feitas nas escolas frequentadas pelos bolsistas, confeccionados e entregues folhetos informativos sobre compostagem.

\section{Palavras-chave:}

Compostagem, compostagem caseira, resíduos sólidos domiciliares.

\section{Introdução}

A compostagem é um processo natural em que os microorganismos são responsáveis pela degradação da matéria orgânica, transformando-a em composto utilizado como adubo orgânico, reduzindo a quantidade de resíduo disposta de forma inadequada. Desta forma, a compostagem se apresenta como uma excelente alternativa para reduzir a quantidade de resíduos orgânicos destinada aos aterros, e ao mesmo tempo promover o uso do composto orgânico como corretivo de solos.

Neste projeto foi abordada a importância da compostagem, na modalidade em pequena escala (ou compostagem caseira) com os alunos bolsistas do Programa PIBIC-EM.

\section{Resultados e Discussão}

Foi realizada uma revisão de literatura sobre o tema, e o processo de compostagem pôde ser acompanhado na prática pelos alunos, que auxiliaram no monitoramento de quatro composteiras de pequeno porte: composteira de pilha, de caixa, de gaveta e de tambor.

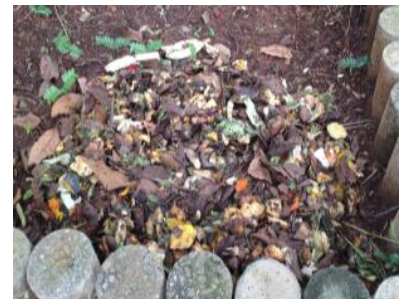

Fig. 1. Pilha.

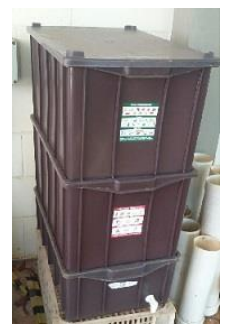

Fig. 3. Gaveta.

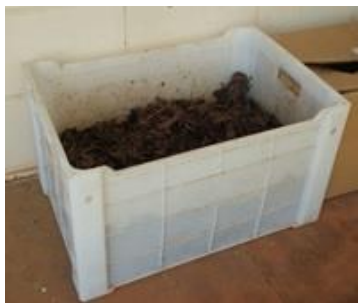

Fig. 2. Caixa.

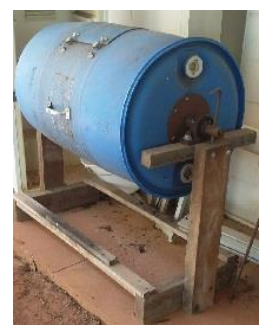

Fig. 4. Tambor.
Os sistemas foram monitorados por cinco meses, três vezes por semana, observando os seguintes parâmetros: temperatura, oxigenação e umidade.

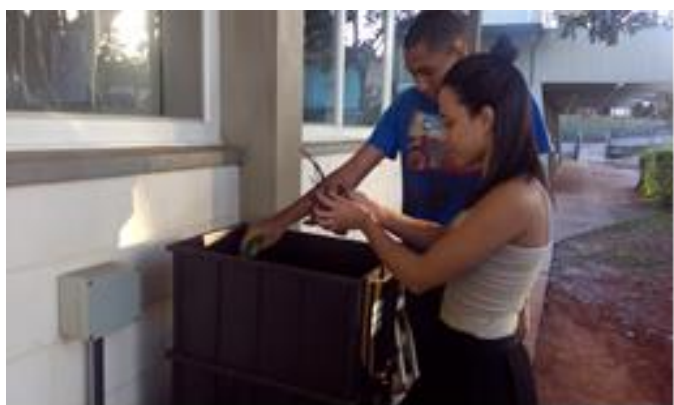

Figura 5. Alunos monitorando a composteira de gaveta.

O monitoramento das composteiras mostrou que a umidade se manteve alta no tambor e na gaveta, com odor desagradável. A composteira de pilha e caixa não apresentaram odores, provalvemente pela maior troca de calor e gases com a atmosfera. Verificou-se uma variação nad temperaturas nas diferentes composteiras, não sendo possível identificar de forma clara as diferentes fases da compostagem.

Com a intenção de multiplicar o conhecimento adquirido, foram realizadas apresentações nas escolas, falando da experiência da participação no programa, o aprendizado e práticas do tema e desenvolveram folhetos informativos sobre compostagem.

\section{Conclusão}

Este projeto mostrou aos alunos de Ensino Médio que a compostagem caseira é uma boa alternativa para a minimização dos resíduos orgânicos. A técnica pode ser implantada facilmente dentro das casas ou escolas utilizando diversos modelos disponíveis. A separação dos resíduos na fonte geradora (casas) garante maior eficiência e menos contaminação do material, além de incentivar a coleta seletiva.

\section{Agradecimentos}

Ao Programa PIBIC-EM pela bolsa concedida, e às Escolas Profo Paulo Chaves e Brasil pelo incentivo à participação no projeto. 